\title{
Implications of the industrial revolution for the family and for the family education
}

\section{Dorin Opriş}




\title{
Implications of the industrial revolution for the family and for the family education
}

\author{
Dorin Opriş ${ }^{a^{*}}$ \\ ${ }^{a}$ Faculty of Law and Social Sciences, "1 Decembrie 1918" University of Alba Iulia, 5 Gabriel Bethlen, Alba Iulia, 510009, Romania
}

*Corresponding author: dorin.opris@uab.ro

\section{Abstract}

Keywords:

industrial revolution; family; education; migration; educational research.
This paper presents an analysis of the contexts and implications of the industrial revolution for education and family, especially in its early stages. The main defining social aspects for the period after the development of the industry were the increase in the living standard, the development of transports and communications, the acceleration of the urbanization. All of these have experienced successive stages of increase or progress, based on the development of technology in developed countries, but an analysis of the implications they have had for family education and in terms of relationships between family members is all the more necessary since many problems from the previous stages remain current. The accelerated industrialization also brought with it the need to travel to different jobs, which led to a gradual decrease the time children could spend with their parents. In the current social context, marked in the world by an increasing rate of labour migration and implicitly by new challenges regarding education and relationships between family members, we have identified recurring hypostases and we synthesized a set of possible research topics able to offer data relevant to support the family in exercising its educational function.

\section{Zusammenfasung}

\section{Schlüsselworte:}

Industrielle Revolution; Familie; Ausbildung; Migration;

Bildungsforschung.
In diesem Beitrag werden die Kontexte und Auswirkungen der industriellen Revolution, insbesondere in ihren frühen Stadien, auf Bildung und Familie analysiert. Die wichtigsten sozialen Aspekte für die Zeit nach der Entwicklung der Industrie waren die Erhöhung des Lebensstandards, die Entwicklung von Transport und Kommunikation, die Beschleunigung der Urbanisierung. All diese sind auf der Grundlage der technologischen Entwicklung in den Industrieländern aufeinanderfolgende Wachstums- oder Fortschrittsphasen durchgelaufen. Gerade deswegen, eine Analyse ihrer Auswirkungen auf die Familienerziehung und auf die Beziehungen zwischen Familienmitgliedern ist notwendig, um so mehr, dass viele von ihnen in den vorherigen Phasen der festgestellten Probleme aktuell bleiben. Die beschleunigte Industrialisierung brachte mit sich auch die Notwendigkeit zu anderen Berufe zu wechseln, was dazu führte, dass die Zeit, die Kinder mit ihren Eltern verbringen konnten, allmählich abnahm. Im aktuellen gesellschaftlichen Kontext, der weltweit durch eine zunehmende Arbeitsmigration und implizit durch neue Herausforderungen in Bezug auf Bildung und Beziehungen zwischen Familienmitgliedern gekennzeichnet ist, haben wir wiederkehrende Hypostasen identifiziert und eine Reihe möglicher Forschungsthemen synthetisiert, die relevante Daten für die Unterstützung der Familie bei der Ausübung ihrer erzieherischen Funktion anbieten.

\section{Introduction}

The increasing steps taken by technology and implicitly industry in its stages of development have made the historical period after the beginning of the emergence of production technology and until now be generically called the Industrial Revolution, and then be divided into four stages (Banabic, 2018). The first industrial revolution began in the late eighteenth century, after the advent of the steam engine, which led to the rapid development of the industry. From a social point of view, the changes were major, as people and goods benefited from great mobility, both in a much shorter time over very long distances. The second industrial revolution (early nineteenth century) was marked by the emergence of electricity and the implementation of production on assembly lines. The third industrial revolution (after 1970) was marked by the development of automation in the industry, by the appearance of the possibilities to realize the remote control and by the integration of programmable computers with memory. The fourth industrial revolution, the current one, is called "Industry 4.0" and it is the next step in automating production by interconnecting the Internet of all systems involved in industrial processes (Desouttertools, 2021).

The factor that stimulated most of the changes brought by industrialization was the separation 
between the concept of producer and that of consumer (Urseioana, 2012). The implications for the social environment, for the family and especially for the children, in their personal development, generated by the last three stages of the industrial revolution were found in the constant increase of the access to information and communication sources, of the living standard, but also in moving family members over increasing distances to work (Minge-Kalman, 1978). This phenomenon culminated in the massive labour migration to developed countries or regions, which led to an increase in time that children spend with other people than their parents or family and major changes in the cultural patterns adopted by family members (de Gabriel, 2014).

Despite all these major changes and difficulties, a certain support for family education came from models taken over and capitalized on based on the remarkable results of some schools in Western Europe (Roberts, 2013), from the pre-industrial period.

\section{Methodological aspects}

The present study aimed to investigate from an educational perspective the major changes and difficulties that the family went through, especially in the first part of the industrialization period, on issues related to its internal cohesion, changes in traditional roles of its members. A bibliography that included interdisciplinary analyses was used, in order to illustrate as many aspects of this issue as possible. Given the complexity of the analysed aspects, we argued the necessity for new educational investigations, for which we proposed some research topics and aspects that we consider a priority. Our research interest on this issue is also related to the evolutions of educational roles in the current family, with an additional emphasis on the situation in Romania. The context is that of the framework of current massive migration, which began more than two decades ago, which often leads to separation from parents or less and less time that children spend with them, aspects that find a significant correspondent in the developments of the first periods of industrialization.

\section{The family during the industrial revolution and the education of the future adult}

The development of industry led to major changes in society, and these needed changes in the classical paradigm of forms of organization, including the family, without which the development was not possible at the expected level (Cope, 1922). For the industrial period, research shows that the emphasis has been increasingly on the well-being of the child, who has become the centre of family concerns, with the status of the new ideal of the family (Hofstetter, 2012). This fact brought a first major change in terms of organization, but also family education. Even if it is in agreement with the paradigm of the Enlightenment, determinant at the time, many research questions arise permanently, including after our previous research, related to the impact that this new status of the child has on his development, but also on parents and family, in its ontological structure (Opriş \& Opriş, 2011). When the child reaches adulthood and leaves the family, parents can easily ask themselves what is still the meaning of their own existence, to see the decrease in cohesion, to ask questions about the meaning of being together of its members (MingeKalman, 1978). Because the child grows in the family and he is training for life and for the cohesion of his own family, the defining model for the child is the one seen and lived, less the learned one, theoretically, reason for which the formative experience, direct, from the family can hardly be supplemented by the learning experiences he benefits from in school contexts (Ionescu, 2007).

The interest in the well-being of the child (Hofstetter, 2012) is legitimate in so far as it is subordinated to the desideratum of supporting his personal development. Research data shows that personal items, his physical condition and in general, the aspects that make his life comfortable and beautiful can end up being overly supported by his parents, to the detriment of the interest in personal training and becoming. The mechanism of obtaining the material things that the child needs or that the parents and in general, the adults around him think that he needs can create an unjustified enthusiasm, able to disturb the correct understanding by the parents of his needs, and through it to contributes to building a false image of the world and values, including education and family. This is one of the causes of the personal failure of the future adult, being accentuated by the impact of social migration (Schreuder, 2014). The lack of prioritize values in the family can also contribute significantly to the failure to form the character of the future adult (Akşit, 2013), with an impact on shaping the child towards the correct relationship with himself and those around him, aspects to which the finalities of moral education (Nicola, 2000) refer constantly. 
The pertinent analysis made more than a century ago by Henry F. Cope insists that a major problem in the modern period for families with a good financial situation remains the way to create a favourable and correct self-image of the child, from which he, in equally, to recognize the value of work, to love the truth and life in communion with others, to have a correct motivation for one's own personal and professional development (Cope, 1922), as well as for helping those in difficult situations.

\section{Sunday school, the great chance of education in the context of the development of industrialization}

The industrial revolution contributed greatly to the dissolution of the traditional family model, in that it largely shifted labour from home to remote areas. It was added to this the increase the number of jobs on farms and in shops, which significantly reduced the degree to which obtaining the material values necessary for living is still a family act, a strong social fact (Mesquita, 2012). This change has had a major impact on education from family: it has increased the extent to which children and young people have acquired from parents, especially from the father, new knowledge and skills in areas required by the labour market, but with the price of maturity fast and often forced, with the decrease in the time they went through the early stages of life, including the seven years of education at home and with parents, or training through the classic games of childhood, increasingly replaced by others related to the work of parents in various factories, workshops, shops.

The confessional schools, including those that appeared in Protestant spaces (Rutz, 2012), could not make up for either the lack of a state-funded education system or the reduced concern for girls' education in a formal context (Akşit, 2013). A research question that is still being answered, including for the current period, is related to the work started since childhood, to the role it plays in going through the stages of personal development, about the possible extent to which it supports the increase of aggression at that age, against the background of increasing the promotion at European level of history works that promoted heroic characters (Meirlaen, 2012).

So, at this historical stage, the family moved to a new stage of material development, but it lost in unity and in the coherence of establishing and respecting educational norms, which were managed with increasing difficulty by the mothers left at home.
The role of parents has been largely taken over by the school, in the context of industrialization (MingeKalman, 1978). If this stage is undisputed a big step forward for school, it is a major setback in relation to the responsibilities understood and traditionally respected for the family. It is the period in which the idea of public schools is imposed, although the state's investment in these institutions was still only the desideratum of the great pedagogues of the time. The year 1780 can be considered a landmark for the gradual delegation by the family to the first schools in England of the responsibilities for the education of children. It is the time of the beginning of the Sunday school in which, in 1831, approximately $1,250,000$ children were enrolled and studied weekly, respectively $25 \%$ of the population (Cope, 1922).

Following the model and experience of these schools, state-sponsored educational institutions were soon organized, to which the family gradually delegated most of the education of poor children (Mesquita, 2012) for profession and for life. After losing their father's educational support, teenagers begin to lose communion with other family members, with the widespread practice that they, especially boys, but not only, often work four to five hours on weekdays, including hard work, such as mining. The mothers were left almost alone at home, taking responsibility for raising the children. This new situation was later considered a true sale of family communion classes (Cope, 1922), and the consequences were not long in coming to the level of family unity and the harmonious education of children. The increase in family income has led to the diversification and increase in demand for household and personal items and objects, to the change in food expectations, to the emergence of spaces for food preparation for an entire community. Thus, the abandonment of traditional family education (MingeKalman, 1978) was followed by the debasement of the common activities of parents and children, generated significantly by the increased interest in community cuisine, often for larger communities, from which it reached high forms and increasingly expensive, later called restaurants. It is the stage in which the classical family, which for centuries gave the major coordinates of the formation of children, has entered a sharp decline and its unity is increasingly limited to hours of sleep and recreation (Cope, 1922). 


\section{Family education and the new socio-cultural models of the 19th century}

From a complete unity, at the beginning of the industrial revolution, the family gets to ask itself if it is not the victim of its own desires for a better life. As in any period of major change, the family did not anticipate the major losses it would experience as a result of the changes in the lives of some of its members. The family felt that it could meet the new challenges or that the benefits of the new lifestyle would compensate for any losses in the education of children and their unity, as had happened in previous stages of social development. In addition to the changes in family life, there were those in the daily life of the community, especially in rural areas. Starting from the landmarks of the Greco-Roman space (Lawton \& Gordon, 2002), education in and for was one of the cornerstones of the Christian formative model, a recurring theme in biblical and patristic literature, raised to the rank of educational principle by modern pedagogy. However, the educational function of the community, especially in rural areas, has experienced a permanent decline, reaching the last decades of the second Christian millennium to reach a minimum level, almost symbolic.

Thus, not only the work and the acquisition of the necessities of family life have ceased to be a unitary approach of parents and children, but also their education is increasingly taken over by other institutions or educational environments, many of them insufficiently prepared or not explicitly intended for this purpose. If the formation on cognitive aspects obviously knew new stages of development, the moral formation in the family and community suffered the most during this period. All this, in the context of new socio-cultural models, often in contradiction with the precepts of the family, values that came into contact with adolescents who left home to work on farms, shops, workshops or factories.

The diminution of the communion between the family members also materialized through the loss of the time spent in the evening together, hours destined for reading or other common activities. In their place, the commercial entertainment came, initially intended for young people in urban areas, for which the personal program began to be more and more different from that of parents. It is illustrative the fact that in the USA the urban population increased between 1800 and 1900 , from $4 \%$ to $40 \%$ in this regard. The axiological change, supported by the increase of the living standard, determined the increase in expectations towards the living space and the separate rooms often appeared in large buildings. People changed their lifestyle, they accepted, for economic reasons, the agglomeration of houses and the sacrifice of green spaces, gardens and natural playgrounds for children, the connection that previously existed with the nature (Cope, 1922).

Traditional family life has partially continued to be a reality in rural communities. One of the relevant contexts in this regard was keeping the custom of eating together once a day, especially in the evening, followed by the development of leisure activities together, all while maintaining the consciousness of life "at home". Under the pressure of the city, however, the village gradually changes its ideals, urban habits are increasingly accepted, the social standard is set in the city, and the debasement of the village is accentuated by the growing criticism of young people moved to the city. For this entire context, the question that people have asked themselves is: What are the components for which this new lifestyle can be considered better than the abandoned one? (Cope, 1922) The answer could only be a nuanced one, because a person cannot be expected to live in material conditions or in difficult social contexts, just to maintain a cultural-educational paradigm considered by many to be already classical. In addition, all new aspects of accelerated urbanization cannot be categorized as negative, even if the sets of values are getting more, being on conflicting positions, including as a result of the increasing diversity of human communities.

\section{Research topics and questions in the context of new family ideals}

The rationales and analyses presented above, the complexity of the issue involved in changes in education within the family, especially in the current Romanian context of mass migration, in which a difficult number of children, estimated in 2018 across the country the figure was approximately 100,000, with the largest share in Suceava County (Spiridon, 2018), indicates a series of priority topics and leads us to questions for interdisciplinary research (Bocoş, Opriş \& Opriş, 2006), with tools from the field of education sciences, which have the difficult task of identifying models and solutions to support the family in the efforts that this fundamental institution undertakes for the training of the new generations by relating to perennial values. 
The first topic starts from the growing number of divorces, for which we consider it is important to identify answers to research questions such as: How can be explained the changes in families of today, expressed through the high divorce rate, the increasing number of young people living together and giving birth to children out of wedlock? What is the relationship between the decrease of the educational role of the community, the separation of young families from parents and the leaving of the parental home, between the increase of domestic comfort in young families and the decrease of concerns for civic and moral-religious education of children? What is the role of lost ideals and goals that are traditionally misunderstood and assumed by family members in the growing failure of today's young families?

We also consider that it is important to investigate the degree to which families consider themselves a moral-religious space (Opriş \& Opriş, 2013), and starting from this idea, the way they jointly assume certain social, moral and religious terms, such as serving one's neighbour, humility or love for all people, not just for family. Among the research questions that can be asked on this topic, we mention: What is the connection between the religious life of the family and the moral education of children in the family, in non-formal or informal contexts? What should be the aims of moral education in these contexts (Engelen, Thomas, Archer \& van de Ven, 2018), how can the evaluation be carried out in moral development (Kristjánsson, 2020)? What activities do children prefer to do, in age groups, with their parents and what do they prefer to do alone or with friends in their free time or on holidays, when their parents can be around them and spend more time together? In what circumstances do personal desires no longer respond or correspond to classical social responsibilities and in what way do the postmodern life coordinates of adolescents or young people mark their relationships with their parents? What are the defining elements in the formation of young people, so that they take seriously their own formation and, subsequently, the moral-religious education of children in their own family? Is it necessary to educate adolescents and young people to have their own family, their own home, respectively to live separately from their parents (Cope, 1922), depending on their particularities of socio-emotional development (Colareza \& Neacșu, 2021)?

Regarding the new social ideals, we consider it is important to investigate, in relation to different categorical variables, the way in which the priorities in the social field are established, but also the impact they have on education. It can provide relevant data on investigative approaches based on research questions such as: Is there a link between dining together or separately, including in the city, going on holiday or short trips often / on weekends and different priorities that family members may have? What are the ways to achieve social and moral-religious education for children from families who spend little time together during the week? What is the role of men and respectively, of women, in establishing the ideals of the postmodern family, compared to those in the early period of industrialization? Is the discussion related to the feminization of men real, in the context in which, in education, female teachers work mainly? If so, what is the impact on the education for social and family responsibilities of adolescents (Șiţoiu, Pânișoară, 2021)? What are the conditions for success in life that young people must observe in the family, compared to their emotional peculiarities (Sobe, 2012) and the ability to cope with difficult personal situations (Opriş \& Opriş, 2012), to the goals of contemporary school, to the moral-religious norms etc.?

\section{Discussions \& Conclusions}

The changes that appear both in terms of impact and social benefits, respectively costs, involved in successful family education make the training efforts carried out in the formal space to know more and more concerns and questions, starting with the way traditional roles of the family know significant changes in current society, compared to the early period of industrialization. The redefinitions regarding the relationship and the possibilities of cooperation between school and family, as fundamental institutions in the formation of the new generations for the family and for the social life, cannot be excluded from here. The research we consider a priority, previously marked at the level of topics, challenges or research questions, can get developments and deepening starting from the realities of education in the traditional family: the children's training to appreciate what the family can offer them, in harmony with those around you, educating the attention to the needs or expectations of other family members or people in the membership groups. All this in the current context, marked by the growing self-concern of young people, supported by the development of the Internet, the instant communication of information and images over very long distances. We consider that the extent to which young people have relevant information about the 
implications of maintaining a home is not sufficiently researched, and the material difficulties they face when they end up living alone put them in difficult situations in family and society.

\section{Authors note:}

Dorin Opriş is Associate professor doctor in the Teacher Training Department, Faculty of Law and Social Sciences, "1 Decembrie 1918" University of Alba Iulia. He specializes especially in the following disciplines: General Didactics, Didactics of Religious Education, Didactics of Informatics, History of Educational Ideas, Methodology of Educational Research. He is the sole author or co-author of numerous books, many of them indexed in libraries in the European Union. He is also the sole author or coauthor of articles published in scientific journals in the country or abroad.

\section{References}

Akşit, E.E. (2013). Women, education, and agency, 16002000. History of Education: Journal of the History of Education Society. 42(2), 287-289. Available at: http://dx.doi.org/10.1080/0046760X.2012.754504.

Banabic, D. (2018). Evoluţia tehnicii şi tehnologiilor de la prima la a patra revoluţie industrială şi impactul lor social. Discurs de recepţie în Academia Română. Available

at: https://academiaromana.ro/sectii/sectia08_tehnica/doc20 18/2018-0926-Banabic-DiscursReceptie.pdf (accessed at 07.10.2020).

Bocoş, M., Opriş, D. \& Opriş, M. (2006). Cercetarea în domeniul educatiei religioase şi al educatiei morale: modele şi aplicaţii. Cluj-Napoca: Casa Cărţii de Ştiinţă.

Colareza, C. \& Neacșu, I. (2021). Addictive Behavioural Manifestations of Adolescents in Romania. Educatia 21 Journal. 20, 5-14. Available at: Doi: 10.24193/ed21.2021.20.01.

Cope, H.F. (1922). Religious Education in the Family, Illinois. Available at: HOT FREE BOOKS - Religious Education in the Family - Henry F. Cope (accessed at 05.03.2020).

de Gabriel, N. (2014). Official and popular culture in the schooling process. Paedagogica Historica: International Journal of the History of Education, 50(4), 514-532. Available at: DOI: 10.1080/00309230.2014.899372.

Engelen, B., Thomas, A, Archer A. \& van de Ven, N. (2018). Exemplars and nudges: Combining two strategies for moral education. Journal of Moral Education. 47(3), 346-365. Available at: DOI: 10.1080/03057240.2017.1396966.
Hofstetter, R. (2012). La transformation de l'enfant en écolier (du 19e au milieu du 20e siècle): les "eurêkas" des sciences de l'homme naissantes, entre scientisme et romantisme: un "naturalisme" de l'enfance. Paedagogica Historica: International Journal of the History of Education. 48(1), 31-50. Available at: DOI: 10.1080/00309230.2011.644631.

Ionescu, M. (2007). Instructie şi educaţie. Ediţia a III-a. Arad: Editura Universităţii de Vest "Vasile Goldiş".

Kristjánsson, K. (2020). An introduction to the special issue on wisdom and moral education, Journal of Moral Education. 49(1), 1-8. Available at: DOI: 10.1080/03057240.2019.1705041.

Lawton, D. \& Gordon, P. (2002). A History of Western Educational Ideas. London•Portland: Woburn Press.

Meirlaen, M. (2012). Old narratives adapted: PostNapoleonic history education and its relation to the present in the Southern Netherlands (1815-1830). Paedagogica Historica: International Journal of the History of Education. 48(6), 810-824. Available at: DOI: 10.1080/00309230.2012.709528.

Mesquita, L. (2012). The Lancasterian monitorial system as an education industry with a logic of capitalist valorisation. Paedagogica Historica: International Journal of the History of Education. 48(5), 661-675. Available at: DOI: 10.1080/00309230.2012.658159.

Minge-Kalman, W. (1978). The Industrial Revolution and the European Family: The Institutionalization of 'Childhood' as a Market for Family Labor, Comparative Studies in Society and History. 20 (3), 454-468. Available at: https://www.cambridge.org/core/journals/comparativestudies-in-society-and-history/article/abs/industrialrevolution-and-the-european-family-the-institutionalizationof-childhood-as-a-market-for-familylabor/8C22515D03F452A707BDACDB67F060FC.

Nicola, I. (2000). Tratat de pedagogie şcolară. Ediţia a IIa, revizuită. Bucureşti: Aramis.

Opriş, D. \& Opriş, M. (2011). Religia şi şcoala. Cercetări pedagogice, studii, analize. Bucureşti: Editura Didactică şi Pedagogică.

Opriş, D. \& Opriş, M. (2012). Teenagers' models of understanding suffering. European Journal of Science and Theology. 8(2), 173-182. Available at: http://www.ejst.tuiasi.ro/Files/33/Opris\%20(18).pdf.

Opriş, D. (2019). Educaţie şi religie. Analize, reflecţii, provocări. Cluj-Napoca: Presa Universitară Clujeană.

Opriş, M. \& Opriş, D. (2013). Cercetare şi religie: repere şi demersuri comune. Cluj-Napoca: Eikon.

Roberts, B. (2013). A renaissance education: schooling in Bergamo and the Venetian Republic, 1500-1650. Paedagogica Historica: International Journal of the History of Education. 49(3), 444-446. Available at: DOI: $10.1080 / 00309230.2011 .571431$.

Rutz, A. (2012). Elementary education and the practices of literacy in Catholic girls' schools in early modern Germany. Paedagogica Historica: International Journal 
of the History of Education. 48(2), 283-298. Available at: DOI: $10.1080 / 00309230.2011 .603344$.

Schreuder, P. (2014). Children, families, and states. Time policies of childcare, preschool, and primary education in Europe (Studies in Contemporary European History, Vol.8). Paedagogica Historica: International Journal of the History of Education, 50(4), 557-559. Available at: DOI: 10.1080/00309230.2013.803693.

Șițoiu, A. \& Pânișoară, G. (2021). The Relationship Between the Emotional Intelligence of a 21st Century Adult and His or Her Parental Competence. Educatia 21 Journal. 20, 25-31. Available at: Doi: 10.24193/ed21.2021.20.03.

Sobe, N.W. (2012). Researching emotion and affect in the history of education. History of Education: Journal of the History of Education Society. 41(5), 689-695. Available at: http://dx.doi.org/10.1080/0046760X.2012.696150.

Spiridon, C. (2018). România - ţara copiilor cu părintiii în altă ţară. In Suceava sunt cei mai mulţi copii care au rămas în grija altora. Cum îi afectează asta. Available at: https://adevarul.ro/news/societate/romania-tara-copiilorparintii-alta-tara-In-suceava-cei-mai-copii-ramas-grijaaltora-afecteaza-asta-

1_5bdf2910df52022f7528a11f/index.html (accessed at 06.10.2020).

White, B. (2015). Scapegoat: John Dewey and the character education crisis. Journal of Moral Education. 44(2), 127144. Available at: DOI: 10.1080/03057240.2015.1028911.

*** Revoluția industrială - De la Industry 1.0 la Industry 4.0. Available at: https://www.desouttertools.ro/industry4-0/noutati/628/revolutia-industriala-de-la-industry-1-0la-industry-4-0 (accessed at 07.10.2020).

*** urseioana. (2012). Educaţia societăţii industriale. Available at: Educatia societatii industriale | urseioana (wordpress.com) (accessed at 05.10.2020). 